\title{
Lake Missoula and Its Floods
}

\section{By Kendall L. Johnson}

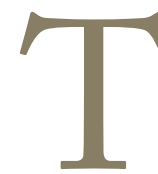

he city of Spokane lies astride the Spokane River, some 40 miles from its origination near Coeur d'Alene, Idaho. The convention center and hotel, site of the 65th annual meeting of SRM, are located right along the river, creating a beautiful and even idyllic setting. These qualities make it even harder to imagine a long-ago day when a miles-wide wall of water, measuring as much as 500 feet high, bore down on this site. Hours before, a great ice dam on glacial Lake Missoula (present-day Clark Fork River) had failed. The dam was as much as 2,500 feet in height, impounded a lake up to 2,000 feet deep, extended east in the intermontane valleys for 200 miles, and covered some 3,000 square miles. It probably contained over 500 cubic miles of water, approximating half the volume of Lake Michigan.

It is now generally agreed that catastrophic floods, in accordance with prevailing ice age conditions, repeatedly issued from Lake Missoula, probably on the order of several tens of times. Geologists estimate that the latest and last of the floods occurred about 13,000 years ago, creating the observable effects on the ground today, while largely obscuring the effects of earlier floods. Most students of the floods support that this particular event and its effects should be named "Bretz's Flood" after the early geologist J Harlen Bretz, who first recognized in 1919 the effects of catastrophic flooding on the Columbia drainage of southeastern Washington, as well as the Columbia River Gorge, the Portland-Vancouver Basin, and the Willamette Valley of Oregon.

Over the 2 million years of the last ice age, four major glaciations advanced into what is now the northwestern United States. The last of these, the Wisconsin glaciation, left clear evidence of its effects, while likely obscuring most of the evidence of earlier flooding. It is near-certain, however, that each of the many floods inundated thousands of square miles in what is now central and southeastern Washington to depths of hundreds of feet. Later study also showed that the many floods likely shared the same provenance, that is, the same cause and effect.

Piecing together the available evidence, it appears that the full glacial climate was cold and dry, with strong winds that redistributed soil materials to the southeastern quadrant of the Columbia Basin. These processes created what is today called the Palouse, an area of wind-deposited silts (loess) over the underlying basalt that had literally oozed out of the earth over previous untold centuries. The winds created dune-like deposits of variable orientation and depth that today make up fertile farmland in southeastern Washington and adjacent Idaho. Bretz's Flood followed the path of the many earlier floods and recreated the effects over thousands of square miles in the Columbia Basin. These can briefly be considered in four major categories: 1) the channeled scablands, 2) the river canyon, 3) the Grand Coulee, and 4) Lake Lewis.

\section{The Channeled Scablands}

The enormous depth of the advancing front of water, measured in the several hundreds of feet, moving at speeds of 50 or so miles per hour, easily overtopped the low hills south of Spokane and poured southwesterly across the basin, stripping away the loess and chiseling through the underlying basalt to create a pattern of braided (anastomosed), steepsided channels, often termed coulees, often with cross-flow hanging valleys. Within the channels, numerous "islands" of loess of many different sizes were left within the flood path, often in a teardrop shape. Elsewhere the flood left bare basalt as the "floors" of the channels where it had not created gigantic potholes and plunge pools, placed gravel deposits of extraordinary sizes in unexpected locations, and dropped huge "erratics" at unlikely spots across the landscape. These became the channeled scablands, covering thousands of square miles in southeastern Washington (Fig. 1). In Bretz's words:

Fully 3,000 square miles of the Columbia plateau were swept by the glacial flood, and the loess and silt cover removed. More than 2,000 square miles of this area were left as bare, eroded, rock-cut channel floors, now the scablands, and nearly 1,000 square miles carry gravel deposits derived from the eroded basalt.

\section{The River Canyon}

Near the southern end of the scabland tract, an east-west trending coulee, now called the Washtucna, formed the channel through which flowed the river now called the Palouse. It appears that when the hard-charging scabland flows entered the upper portions of the valley they captured the river and turned it due south over the valley margins. There the waters began to tumble down southern drainage 


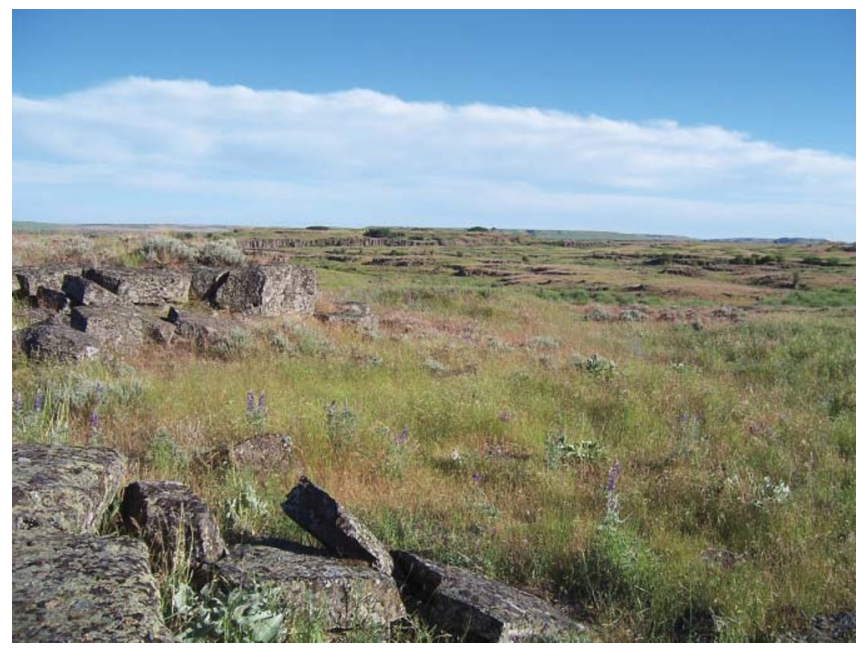

Figure 1. The channeled scablands in southeastern Washington. Photo by author.

routes, eventually becoming a series of stair-step falls and ultimately a major falls of nearly 200 feet. Although impressive, the falls together with the river itself are now out of proportion with the canyon channel (Fig. 2). Clearly, the depth of the canyon, the oversize plunge pool, the width of the waterfall edge, the height of the falls, and the volume of the river itself are indicative of the much larger flows that once occupied the canyon channel of the Palouse

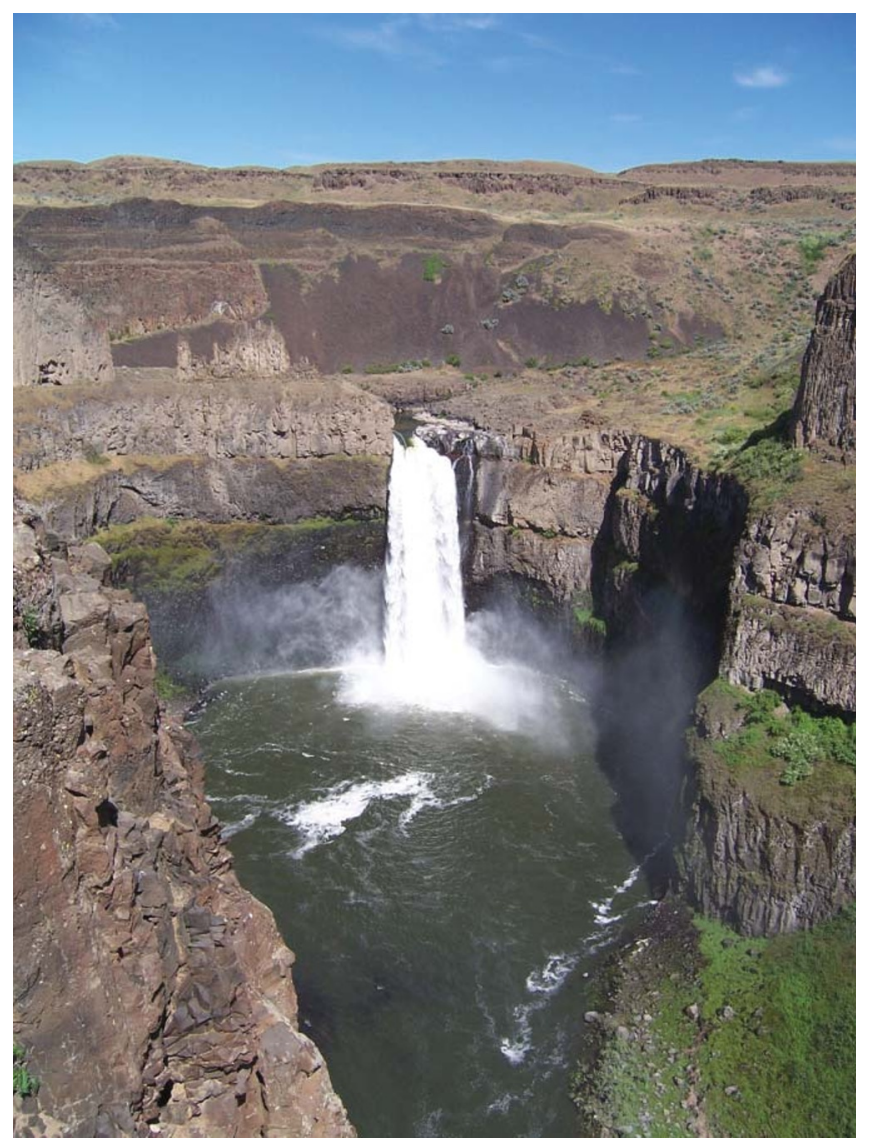

Figure 2. The Palouse Falls. Photo by author.

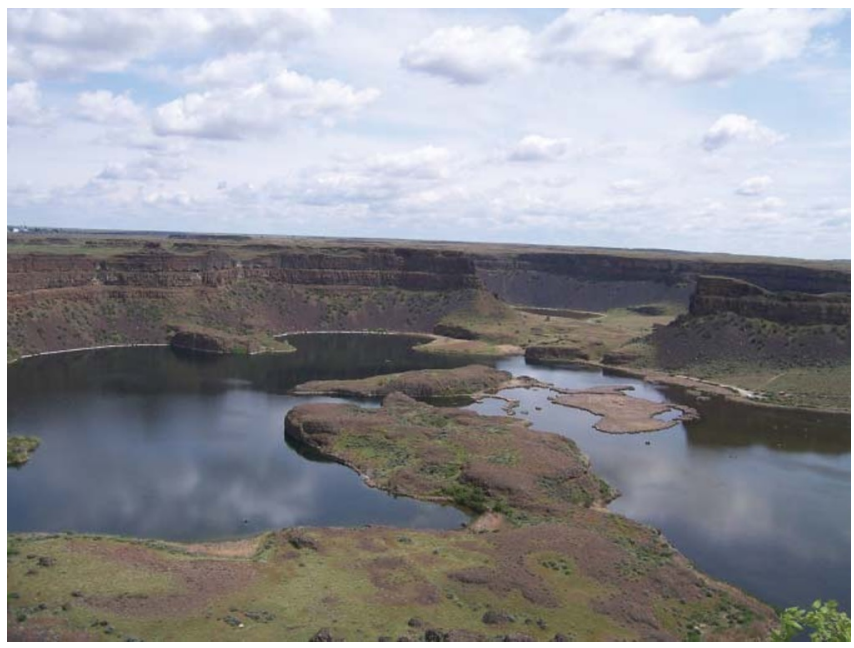

Figure 3. The Dry Falls. Photo by author.

River-once part of Bretz's Flood together with the many earlier scabland flows.

\section{The Grand Coulee}

Not all of Bretz's Flood went down the channeled scablands south of the Spokane area. A large portion continued down the Spokane River to its junction with the Columbia, in turn swelling its flow until it spilled over its banks at a location now called the Grand Coulee. The Grand Coulee had been formed by an earlier extension of the Cordilleran ice sheet, which dammed the Colombia and directed its waters down what became the coulee, with walls several hundred feet high in its upper parts. Bretz's Flood also flowed down the coulee, further deepening and widening the channel. Most of the upper portion of the Grand Coulee now holds Banks Lake Reservoir, a vital component of the Columbia Basin irrigation project.

At the coulee's midpoint, the flood created the most massive, but short-lived, waterfall in the world. Now called Dry Falls (Fig. 3), the cataract fell over a precipice more than 400 feet high and over 3 miles wide, making it the largest such structure in the world. But there was no true waterfall at the time of maximum discharge because the depth of the flood buried the cliffs entirely, creating only a slight drop of the water surface during flood height. Still, as the waters continued to drain away to the southwest, it must have been a most spectacular waterfall.

It is likely that the many floods coursing over the waterfall during thousands of years have eroded its face some 15 to 20 miles from its apparent origination, thus creating what is now the lower portion of the Grand Coulee.

\section{Lake Lewis}

All of the waters flowing through the Columbia Basin as a consequence of Bretz's Flood were draining toward the Columbia River in its west-by-south course around the basin, ultimately discharging from its southernmost point, called the Wallula Gap. Due to the volume of Bretz's Flood, 
however, the Wallula Gap was unable to accommodate all of the water at once. It has been estimated that over 250 cubic miles of water accumulated above the gap, covered more than 3,000 square miles of the basin for a week to 10 days, and reversed the flow of the Snake River for many miles. All this despite the fact that the gap is about 1 mile wide between surrounding walls 750 feet high, with flood marks on top of them. The temporary ponding has been called Lake Lewis. During its short stay as still waters, flood-borne sediments settled out in coarse to fine-graded layers, some of which were later transferred by wind back to areas of the Palouse.

In such a patient, painstaking fashion, J Harlen Bretz divined for himself the cause and effects of the ice-dam failure on glacial Lake Missoula thousands of years ago. He worked on foot, in a time before aerial photography, over hundreds and hundreds of scabland miles. His tools were his native intuition, his keen mind, and his powers of detailed observation. From them he gained an understanding of a truly epochal event in the natural history of the Pacific Northwest.

\section{Additional Reading}

Allen, J. E., M. Burns, and S. Burns. 2009. Cataclysms on the Columbia. Portland, OR, USA: Ooligan Press, Portland State University. 204 p.

Soennichsen, J. 2008. Bretz's Flood. Seattle, WA, USA: Sasquatch Books. 289 p.

Kendall Johnson served as the 52nd president of SRM in 1999 and head of the Range Resources Dept at the University of Idaho from 1988 to 2003. He can be reached at kl_abjohnson@ bughes.net.

\section{Winter Dance-2012}

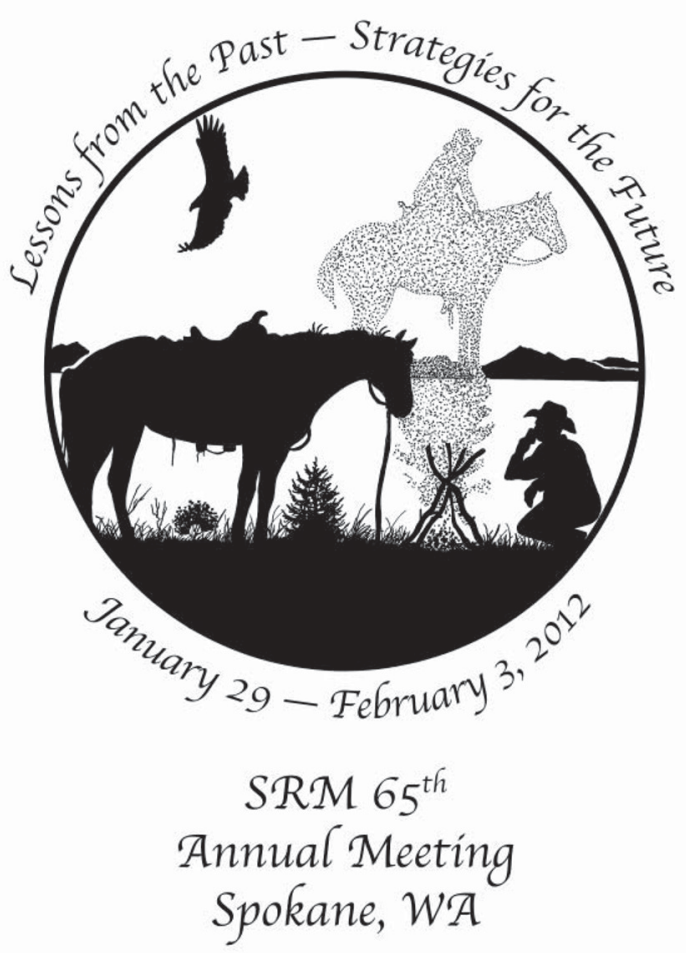

